\title{
VAPB wt Allele
}

National Cancer Institute

\section{Source}

National Cancer Institute. VAPB wt Allele. NCI Thesaurus. Code C124936.

Human VAPB wild-type allele is located in the vicinity of $20 q 13.33$ and is approximately 62 $\mathrm{kb}$ in length. This allele, which encodes vesicle-associated membrane protein-associated protein B and vesicle-associated membrane protein-associated protein C, is involved in the mediation of the response to unfolded proteins. Mutation of the gene is associated with amyotrophic lateral sclerosis 8 and autosomal dominant adult proximal spinal muscular atrophy (SMAPAD). 